\title{
MORPHOLOGICAL VARIABILITY OF FRUITS IN APIUM REPENS (JACQ.) LAG. - A CRITICALLY ENDANGERED SPECIES IN POLAND
}

\author{
KRYSTIAN FLORKOWSKI \\ K. Florkowski, Department of Plant Taxonomy, Faculty of Biology, Adam Mickiewicz University in Poznań, \\ Umultowska 89, 61-614 Poznań, Poland, e-mail: krystian.florkowski@amu.edu.pl
}

(Received: August 2, 2017. Accepted: October 16, 2017)

\begin{abstract}
AвSTRAст. This study presents the variability in morphological features (length, width, shape and volume) of fruits (schizocarps) of Apium repens (Jacq.) Lag. Fruits were collected from plants occurring both in natural conditions and in cultivation under optimal and uniform conditions.

It was found that populations of $A$. repens from the Wielkopolska Province differ significantly in fruit size. Mericarps of plants growing in the Gniezno Lakeland are smaller than those from the Leszno Lakeland. Similar measurements were conducted for mericarps from cultivated populations (initiated on the basis of in situ material originating from wild populations). The Mann-Whitney U test showed that fruits in cultivated populations are bigger and in some cases significantly bigger $(Z=-12.22$ for $p<0.00)$ than those formed in natural conditions. However, the shape of mericarps remained almost unchanged regardless of environmental conditions.
\end{abstract}

KEY WORDS: Apium repens, fruits, variability, in situ and ex situ conditions

\section{INTRODUCTION}

Apium repens (creeping marshwort) is one of the rarest species of Apiaceae family in Europe. The taxonomic status of this species, in relation to the genus affiliation, has been a topic of a lively discussion. Studies of KoczWara (1960) and SZAFer et al. (1967) indicated the species affiliation to Helosciadium Koch. Genus, whereas other sources (Tutin 1968, RutKowsKi 1998, Mirek et al. 2002) included Apium repens in Apium L. genus. Recent research conducted by RonSE et al. (2010) indicated that creeping marshwort should be included in the genus Helosciadium Koch.

Apium repens is distributed from the Iberian Peninsula up to east Germany and north-west part of Balkans Peninsula (Chmiel \& Ziarnek 2012). In Poland, its populations occur in West Pomerania (Miedwie Lake, Liwia Łuża Lake) and in the Wielkopolska Province: Gniezno Lakeland (Powidzkie Lake, Powidzkie Małe Lake) and Leszno Lakeland (Brenno Lake, Białe Lake). Populations in Wielkopolska are isolated and located furthest east in relation to the species compact geographic range in Western Europe.

The population size and preservation of Creeping marshwort in change rapidly. The abandoning of grazing, vegetation succession and changes in lake shorelines connected with tourist recreationare main factors of creeping marshwort's recession (MAREK \& ZabawsKi 1960, ŻuKowski 1961, 1963, Chмiel 1985 , 1987, ŻuKowsKi et al. 1988, ZiARNeK et al. 2010, ChMiel \& Ziarnek 2012, RogozińsKa 2012). Groundwater decrease during drought periods and long term flooding, especially in summer, also have negative impact on the species (Lorenc et al. 2006). Conservation of creeping marshwort's is a priority task for nature conservation service in Poland (JACKOWIAK et al. 2007, Chmiel 2013, Chmiel et al. 2014, Order... 2013, 2015, Regulation... 2014).

In the area of Poland, creeping marshwort flowers abundantly. However, relatively small amount of fruits reach maturity (ŻUKowsKi et al. 1988). As clonal plants, creeping marshwort reproduces mainly in vegetatively by runners (CHмiel et al. 2014). Intensive vegetative spread results in high density of ramets, which leads to poor flowering and restricts the access of pollinators to flowers.

In plants, allocation of resources into vital functions is determined genetically and modified by the influence of environmental conditions. Plasticity of plant development can concern both morphological 
and physiological aspects. According to LaLONDE \& ROITBERG (1989), the shortage of environmental resources, crucial for plant development, may lead to the reduction in seed size. Previously, it was considered that seed size is rather a constant feature within species (HARPER 1977). Subsequent research proved that seed size within population can vary considerably (SiLVertown 1989, ERIKSSON 1999). This diversification is the result of plasticity regarding energy resource allocation (into the plant growth and vegetative and generative reproduction) depending on environmental conditions (SCHMID \& DolT 1994, LeHTILA \& Ehrel 2005, Lembicz et al. 2011).

Up-to-date knowledge referring to morphological diversification of $A$. repens within population and among different populations occurring in Poland in isolated localities was based only on casual observations done during geobotanical research.

The aim of this research was to study the morphological diversification of creeping marshwort mericarps at the intra- and inter population levels in the Wielkopolska Province, in diverse environmental conditions and in cultivation (in uniform conditions) based on material originating from the studied natural populations. This task was part of the project concerning the creeping marshwort preservation in the Wielkopolska region, realised by the Regional Directorate for Environmental Protection in Poznan in cooperation with the Botanical Garden of the Adam Mickiewicz University in Poznań.

\section{MATERIAL AND METHODS}

Biometric measurements were planned for four series of carpological samples: 1. collected from wild populations, 2. collected from cultivated collection, based on the ramets sampled in the field, 3. collected from cultivated collections, based on mericarps sampled in the filed, 4. collected from cultivated collection, based on mericarps originating from cultivation (Table 1). The measurements included: the length, width, shape (proportion of fruit length to width) and volume of 1752 mericarps (Fig. 1). They were made using a stereoscopic microscope connected to a computer equipped with the Cell+ programme. Length and width were measured in micrometers $(\mu \mathrm{m})$, while volume in cubic millimeters $\left(\mathrm{mm}^{3}\right)$. In order to estimate the significance level of morphometric diversification of mericarps from individual samples, the Mann-Whitney U test and STATISTICA 12 programme were used.

In autumn 2014, 37 ramets were collected randomly from wild populations in the following localities: Gniezno Lakeland (Anastazewo, Giewartów, Ostrowo Hutka, Polanowo), Leszno Lakeland (Brenno 2, Brenno OSP, Brenno Ostrowo) (Fig. 2). Due to a highly diversified size of populations and their condition, 1 to 10 ramets were collected from each population. Collected plant material was used to establish cultivation in the Botanical Garden in Poznań.

In autumn 2015, six carpological samples, including 42 to 110 ripe fruits, were randomly collected from each $A$. repens culture (Table 1). After biometric measurements - part of mericarps was preserved for

Table 1. Comparison of research material

\begin{tabular}{|c|c|c|c|c|}
\hline \multirow{4}{*}{$\begin{array}{c}\text { Locality name } \\
\text { (GPS coordinates) }\end{array}$} & \multicolumn{4}{|c|}{$\begin{array}{l}\text { Conditions of sampling and sample size of collected fruits } \\
\text { (number of mericarps) }\end{array}$} \\
\hline & \multirow[b]{3}{*}{$\begin{array}{l}\text { in situ } \\
\text { populations }\end{array}$} & 2015 & \multicolumn{2}{|c|}{2016} \\
\hline & & \multicolumn{3}{|c|}{ ex situ collections } \\
\hline & & $\begin{array}{l}\text { set up in } 2014 \text { based } \\
\text { on ramets collected } \\
\text { in the field }\end{array}$ & $\begin{array}{l}\mathrm{F}_{1}: \text { from sowing seeds } \\
\text { collected in } 2015 \text { in } \\
\text { the field }\end{array}$ & $\begin{array}{l}\mathrm{F}_{1} \text { : from sowing seeds col- } \\
\text { lected from ex situ cultivation } \\
\text { set up in } 2014\end{array}$ \\
\hline $\begin{array}{l}\text { Anastazewo } \\
\text { N } 52^{\circ} 26^{\prime} 21^{\prime \prime} \text { E } 18^{\circ} 0^{\prime} 5^{\prime \prime}\end{array}$ & 51 & $* *$ & 50 & - \\
\hline $\begin{array}{l}\text { Giewartów } \\
\text { N } 52^{\circ} 21^{\prime} 56^{\prime \prime} \text { E } 17^{\circ} 56^{\prime} 51^{\prime \prime}\end{array}$ & * & 75 & - & 42 \\
\hline $\begin{array}{l}\text { Polanowo } \\
\text { N } 52^{\circ} 23^{\prime} 22^{\prime \prime} \text { E } 17^{\circ} 55^{\prime} 52^{\prime \prime}\end{array}$ & * & 107 & - & *** \\
\hline $\begin{array}{l}\text { Ostrowo Hutka } \\
\text { N } 52^{\circ} 26^{\prime} 34^{\prime \prime} \text { E } 17^{\circ} 57^{\prime} 48^{\prime \prime}\end{array}$ & 413 & 110 & 62 & 44 \\
\hline $\begin{array}{l}\text { Brenno } 2 \\
\text { N } 51^{\circ} 55^{\prime} 34^{\prime \prime} \text { E } 16^{\circ} 12^{\prime} 40^{\prime \prime}\end{array}$ & 55 & 80 & 49 & 51 \\
\hline $\begin{array}{l}\text { Brenno OSP } \\
\text { N } 51^{\circ} 55^{\prime} 33^{\prime \prime} \text { E } 16^{\circ} 13^{\prime} 5^{\prime \prime}\end{array}$ & 38 & 42 & 78 & $* * *$ \\
\hline $\begin{array}{l}\text { Brenno Ostrowo } \\
\text { N } 51^{\circ} 55^{\prime} 33^{\prime \prime} \text { E } 16^{\circ} 13^{\prime} 5^{\prime \prime}\end{array}$ & 182 & 98 & 80 & 45 \\
\hline Total & 739 & 512 & 319 & 182 \\
\hline
\end{tabular}

*Populations in in situ conditions that got destroyed or didn't produce fruits in 2015.

**Ramets that didn't survive winter 2014/15 in the Botanical Garden.

***Collection set up on the basis of ramets selected in the field that didn't produce fruits in 2016. 


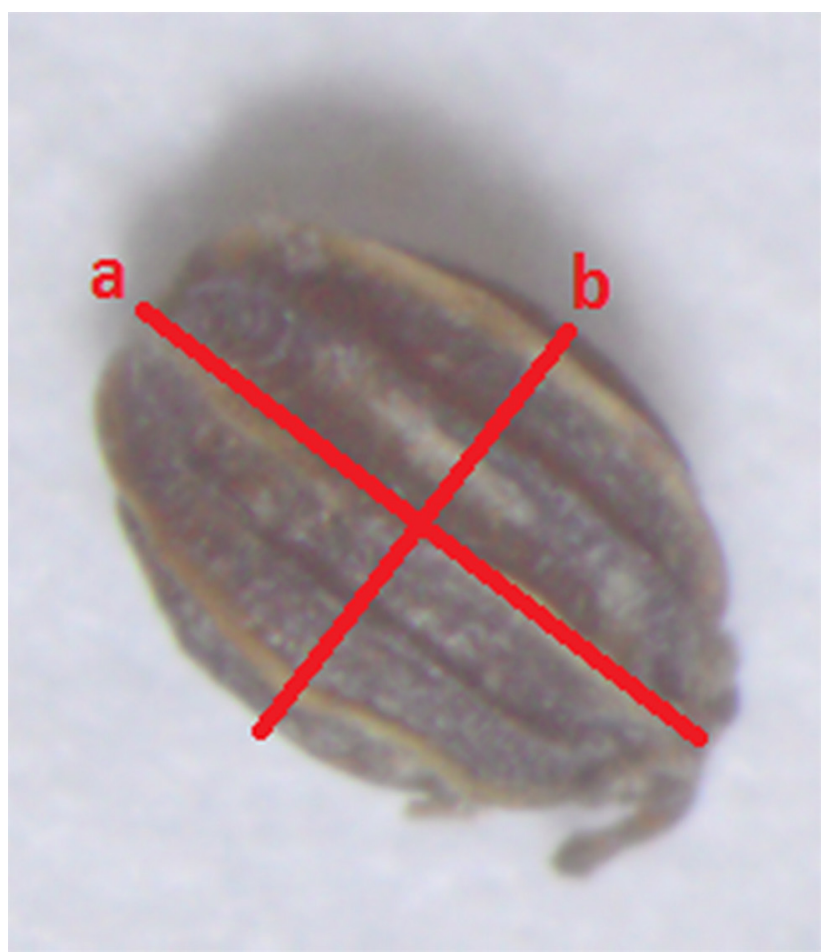

Fig. 1. Apium repens (Jacq.) Lag. fruits measurements method: $\mathrm{a}$ - length, $\mathrm{b}$ - width documentary purposes, while another part, randomly selected from each sample (altogether 60 fruits; 10 per each sample), was used in 2016 to set up $F_{1}$ generation in cultivation conditions. Therefore, in April 2016, mericarps were placed separately in dishes filled with substrate and put into phytotron. During the phase of first runners development, the plants were replanted into flat pots of $20 \mathrm{~cm}$ in diameter and placed in open frame in the Botanical Garden. In autumn 2016, mericarps from $\mathrm{F}_{1}$ generation (182 in total) were collected from each sample for biometric measurements (Table 1).

Analogically, at the end of vegetative season (from the half of October until the end of November 2015) random samples of ripe fruits were collected from populations growing in in situ conditions in the following localities: Brenno 2, Brenno Ostrowo, Brenno OSP, Ostrowo Hutka and Anastazewo. Depending on the population size, the collected samples included 38 to 413 fruits (Table 1). Due to population destruction or the lack of flowering, no fruits were collected from populations in Giewartów and Polanów. Similarly like in case of starting $F_{1}$ generation with fruits collected from cultivation, in May 2016, fruits selected in the field were sown (altogether 50 fruits; 10 per each population). Mericarps collected in autumn 2016 from this culture were also measured biometrically.

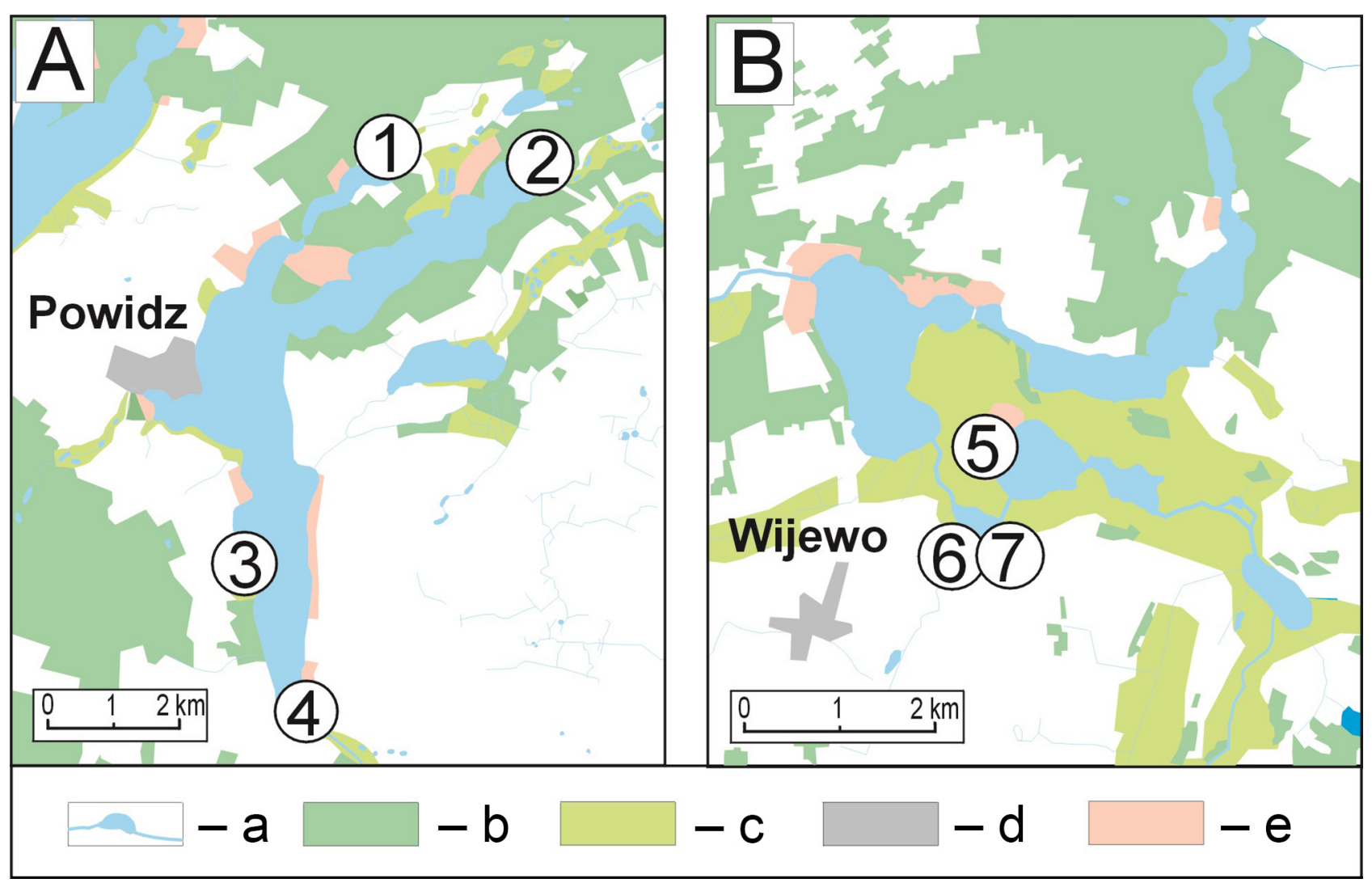

Fig. 2. Sites of ramet and mericarp sampling for cultivation purposes: A - Gniezno Lake District (1 - Ostrowo Hutka, 2 Anastazewo, 3 - Polanowo, 4 - Giewartów), B - Leszno Lake District (5 - Brenno Ostrowo, 6 - Brenno 2, 7 - Brenno OSP)

Legend: a - surface waters, b - forests, c - meadows and pastures, $\mathrm{d}$ - main towns/villages, e - recreation areas. 
Comparative analysis among individual samples were referred to phytogeographical aspects and environmental differences during their development (in situ and ex situ). The aim of biometric analysis of fruits collected in the field and breeding cultivation in even ex situ environmental conditions was to observe the effects of changes in energy resource allocation in the absence of environmental pressure, especially intraspecific competition.

\section{RESULTS}

In most of analysed cases, mericarps from the ramets reproducing generatively in cultivation were considerably bigger than those collected in situ. At the same time, cultivation of ramets collected from in the field (in the first year of cultivation) didn't have positive influence on fruit size. The study showed the following differences in mean fruit size between plants in in situ conditions and in cultivation: in length $=3.86 \mu \mathrm{m}$, in width $=2.12 \mu \mathrm{m}$ and in volume $=0.0013 \mathrm{~mm}^{3}$.

Mericarps collected from populations in the Gniezno Lakeland are shorter than those from Leszno Lakeland. Mann-Whitney U test showed a maximal range of differences in mericarps length between in situ populations in Ostrowo Hutka and Brenno Ostrowo $(Z=-9.7425$ for $p<0.000)$ and minimal between Anastazewo and Brenno $2(\mathrm{Z}=-3.84831$ for $\mathrm{p}=0.0001$ ) (Fig. 3).

Differences in the width of mericarps collected from populations located in the various parts of Wielkopolska are also significant (although not so significant as in case of length). Maximal differences in mericarp width were observed in case of in situ populations from Ostrowo Hutka and Brenno 2 ( $\mathrm{Z}$ $=-6.1324$ for $\mathrm{p}<0.000)$ and fruits collected from ex situ localities in Ostrowo Hutka and, Brenno Ostrowo $(Z=-6.7556$ for $\mathrm{p}=0.006)$ (Fig. 4).

Mericarp shape expressed by the length/width ratio was mostly in the range of 1.4-1.6. The most spherical shape was achieved by ex situ mericarp samples from Anastazewo, whereas the most elongated shape was reached by in situ mericarps from Brenno Ostrowo $(Z=3.735$ for $p=0.0002)$ and these from generative reproduction - collected from ramets selected in Gierwatów and planted in cultivation $(\mathrm{Z}=$ 4.559 for $\mathrm{p}<0.000$ ) (Fig. 5).

Volume of mericarps produced by plants in ex situ conditions (reproducted in generative manner from seeds collected from testing ground in 2015) is bigger than volume of fruits produced in similar in situ populations. It is visible in maximal range in case of samples from Brenno Ostrowo. Differences expressed by Mann-Whitney $\mathrm{U}$ test are: for length $\mathrm{Z}$ $=-12.2407, p=0.000$; width $Z=-1.201, p=0.000$; volume $\mathrm{Z}=-2.220, \mathrm{p}=0.000$.

Volume of mericarps populations from the Gniezno Lakeland mostly achieves values between $0.3-0.4 \mathrm{~mm}^{3}$, while from the Leszno Lakeland 0.4$0.6 \mathrm{~mm}^{3}$. Significant exception from this regularity are volumes of mericarps collected from the cultivation set up on the basis of mericarps selected from in situ population in Ostrowo Hutka (Fig. 6).

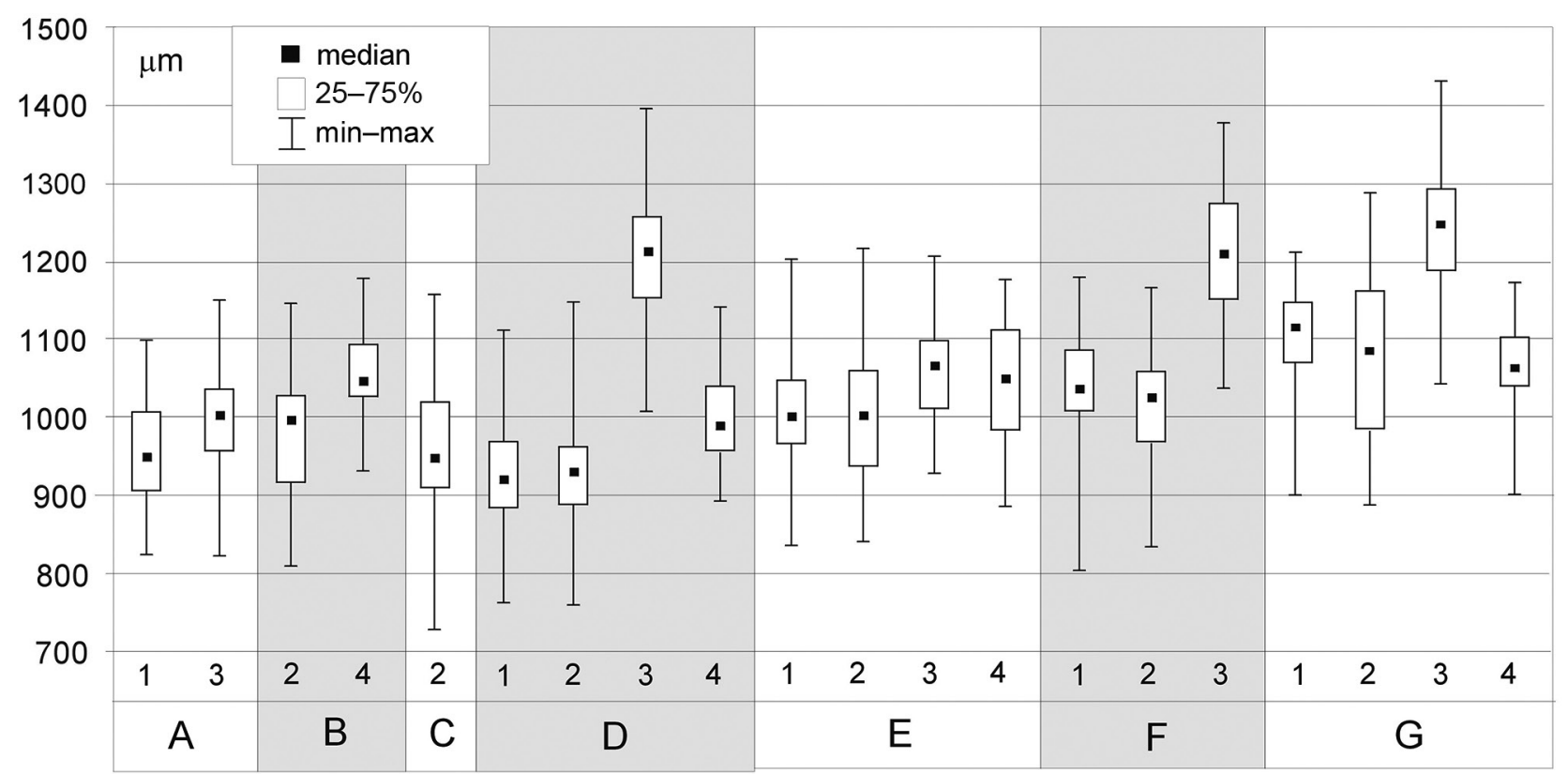

Fig. 3. Variability of mericarp length in populations from: A - Anastazewo, B - Giewartów, C - Polanowo, D - Ostrowo Hutka, E - Brenno 2, F - Brenno OSP, G - Brenno Ostrowo; identification of fruit samples: 1 - collected in situ in the field, 2 - collected from the cultivation of ramets sampled in the field, 3 - collected from $\mathrm{F}_{1}$ generation set up using diaspores sampled in situ, 4 - collected from $\mathrm{F}_{1}$ generation set up using diaspores sampled ex situ 


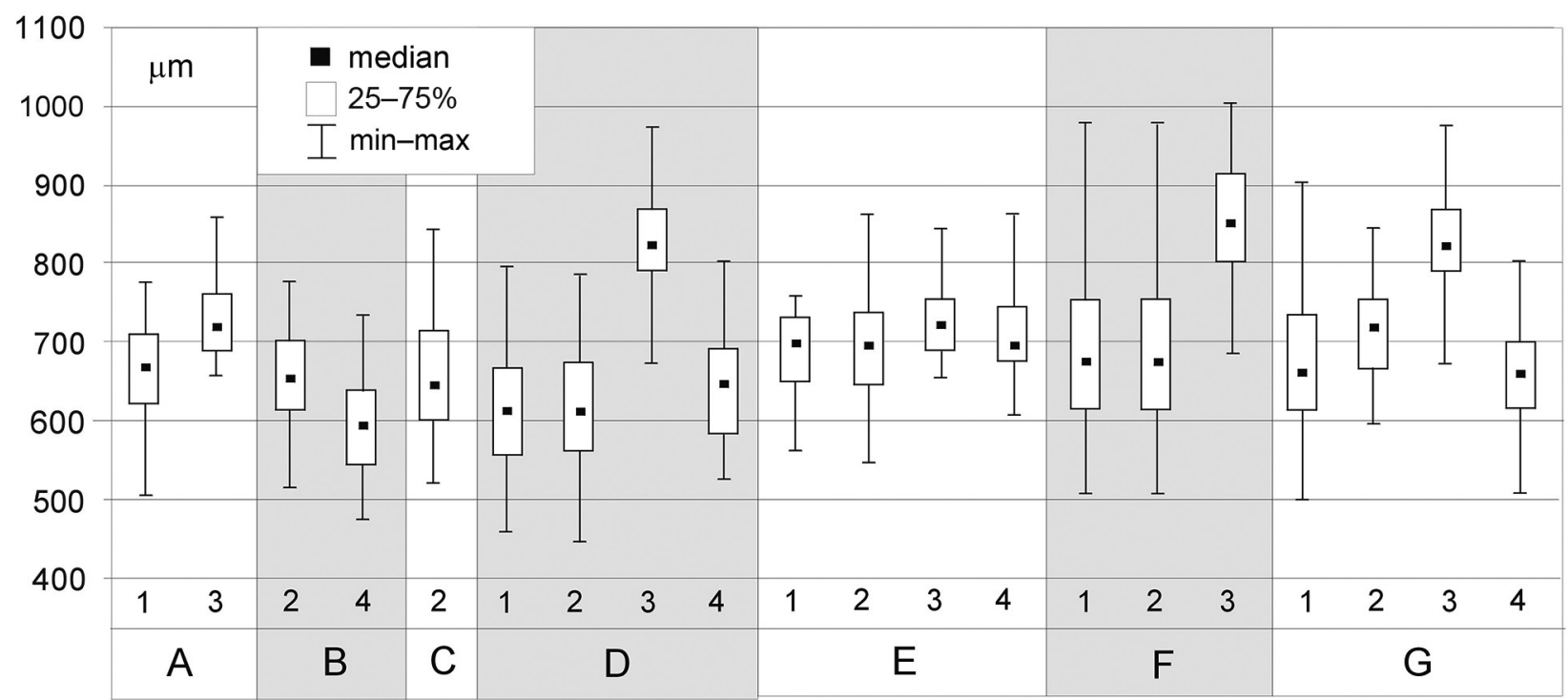

Fig. 4. Variability of mericarp width in populations from: A - Anastazewo, B - Giewartów, C - Polanowo, D - Ostrowo Hutka, E - Brenno 2, F - Brenno OSP, G - Brenno Ostrowo; identification of fruit samples: 1 - collected in situ in the field, 2 - collected from the cultivation of ramets sampled in the field, 3 - collected from $\mathrm{F}_{1}$ generation set up using diaspores sampled in situ, 4 - collected from $\mathrm{F}_{1}$ generation set up using diaspores sampled ex situ

Mann-Whitney $U$ test results (taking maximal values into consideration) for Ostrowo Hutka ex situ collection compared to Brenno Ostrowo are as follows: $Z=-7.646$ for $p<0.000$, and for Ostrowo Hutka in situ population compared to Brenno $2: \mathrm{Z}=$ -7.094 for $\mathrm{p}<0.000$.
A positive effect of optimal environmental conditions on energy resource allocation into generative structures was not confirmed in all studied cases. Collections established from the seeds collected from ramets in in situ populations in Polanowo and Brenno OSP didn't produce flowers during the whole growing season of 2016 (Table 1).

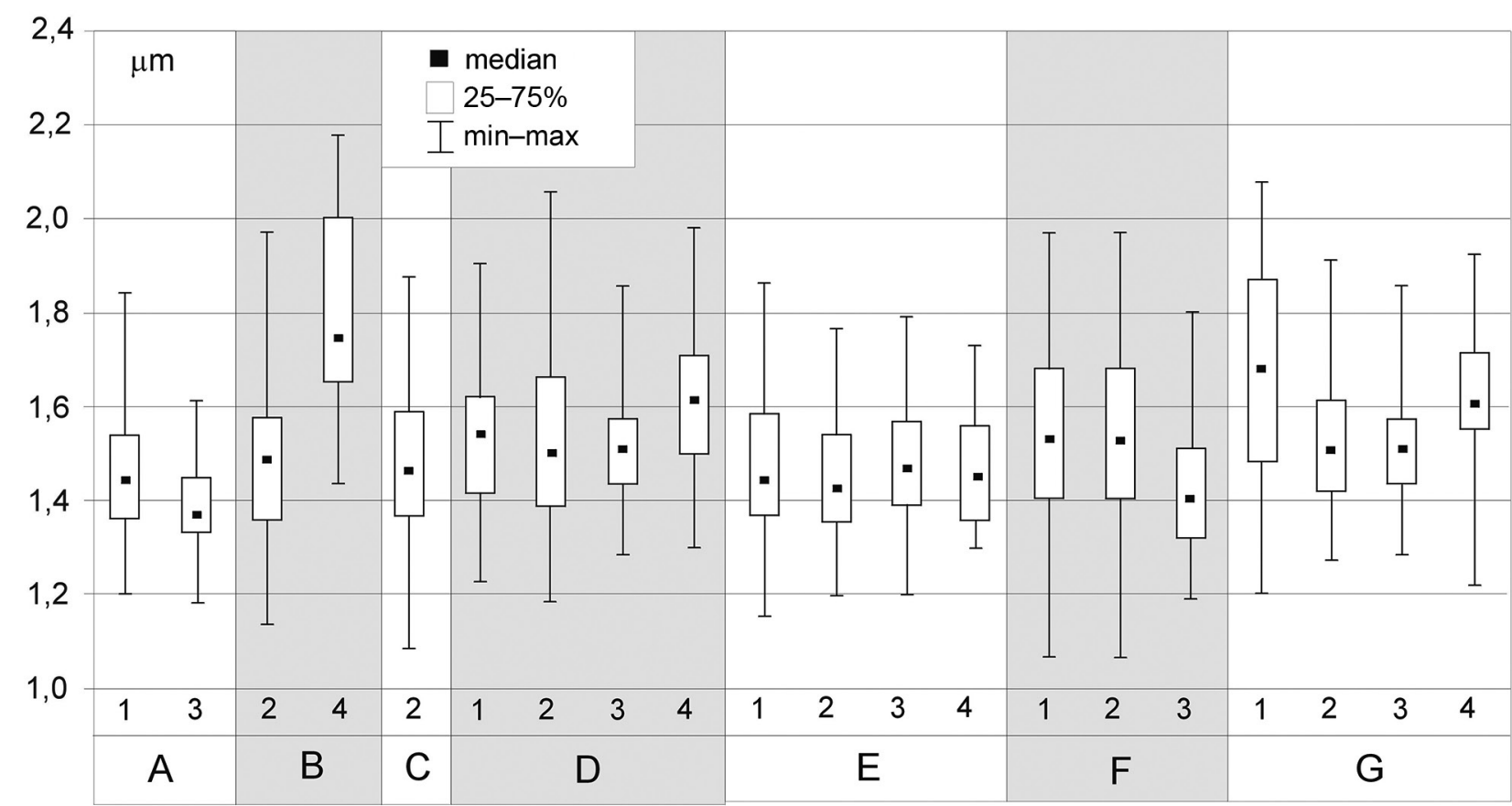

Fig. 5. Variability of mericarp shape (length/width) in populations from: A - Anastazewo, B - Giewartów, C - Polanowo, D - Ostrowo Hutka, E - Brenno 2, F - Brenno OSP, G - Brenno Ostrowo; identification of fruits samples: 1 - collected in situ in the field, 2 - collected from cultivation of ramets sampled in the field, 3 - collected from $\mathrm{F}_{1}$ generation set up using diaspores selected in situ, 4 - collected from $\mathrm{F}_{1}$ generation set up using diaspores selected ex situ 


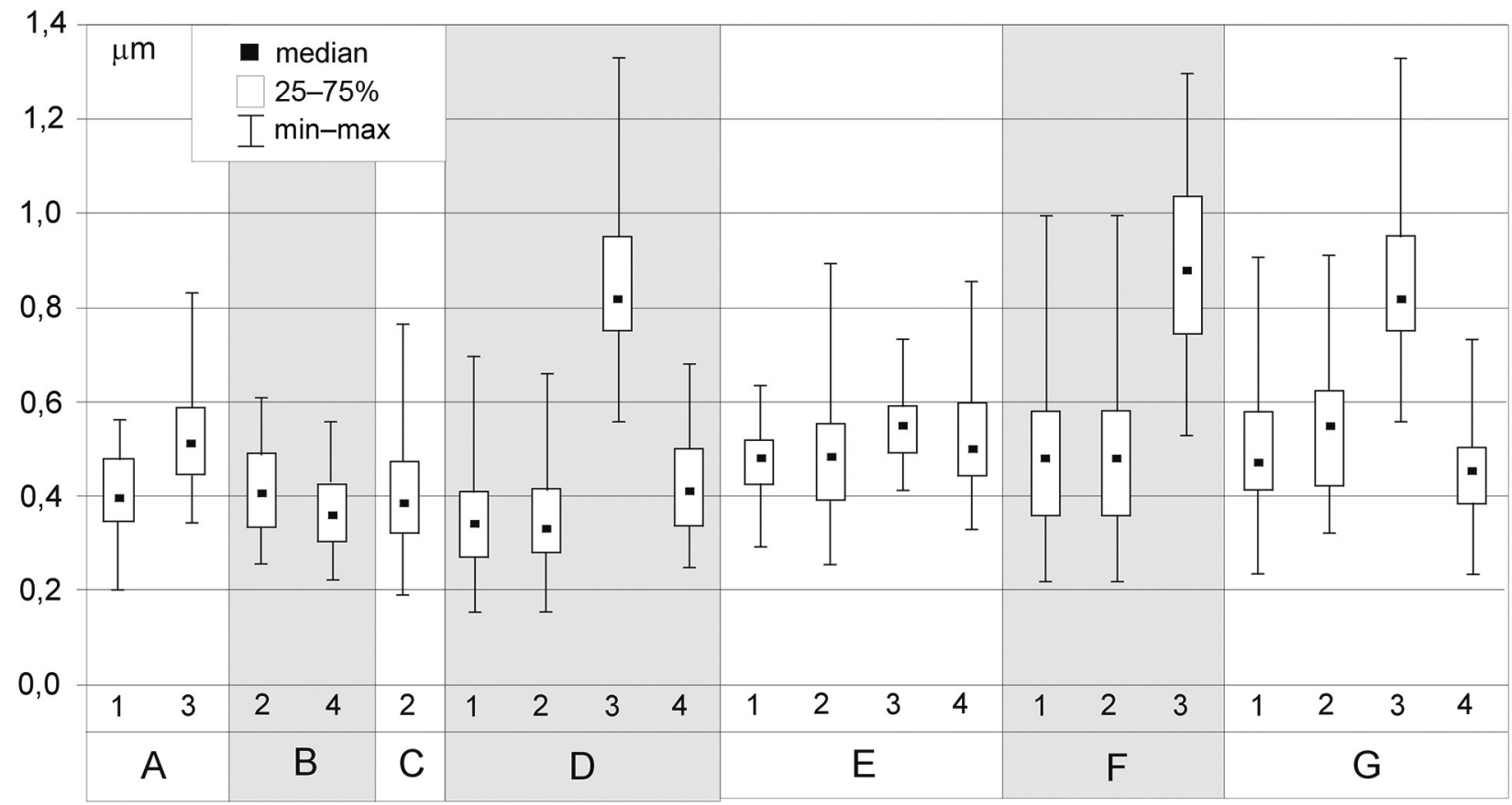

Fig. 6. Variability of mericarp volume in populations from: A - Anastazewo, B - Giewartów, C - Polanowo, D - Ostrowo Hutka, E - Brenno 2, F - Brenno OSP, G - Brenno Ostrowo; identification of fruits samples: 1 - collected in situ in the field, 2 - collected from the cultivation of ramets sampled in the field, 3 - collected from $\mathrm{F}_{1}$ generation set up using diaspores sampled in situ, 4 - collected from $\mathrm{F}_{1}$ generation set up using diaspores sampled ex situ

\section{DISCUSSION}

Biometric analysis showed that creeping marshwort populations from the Gniezno Lakeland produce smaller fruits in comparison to those from the Leszno Lakeland and plants relocated into optimal ex situ conditions produce bigger fruits than in in situ conditions. Isolated populations from the Gniezno Lakeland are located furthest to the east considering Central Europe compact range. In contrast to the Leszno Lakeland, there are less favourable climate conditions for this suboceanic species. Population condition is continuously worsening due to water-level fall in lakes caused mainly by activity of nearby opencast brown coal mine. On the basis of considerable morphometric similarities between fruits from Brenno Ostrowo, Brenno OSP and Brenno 2 populations, it can be assumed that these populations are the remains of previous, large Brenno population.

It was shown (among others, by Mc Ginley et al. (1987) and Lehtila \& Ehrel (2005)) that in more favourable environmental conditions, plants produce bigger fruits. Because $A$. repens is a clonal species that can reproduce vegetatively, the fruit size may depend on the age of ramet network. The network senescence can result in smaller seeds despite the relatively unchanged size of ramets (LemBicz et al. 2011). From the evolutionary point of view - a decrease in gene pool size and impact of competitors may favour the genetic control of seed size (SADRAS 2007). Future experiments are planned aimed at checking whether the size of $A$. repens mericarps may affect the size of seedlings and their rate of development. It is assumed that species producing larger seeds have larger seedlings. Large seedlings develop more slowly and usually are better prepared for growth in habitats characterized by stable and at least sufficient level of resource availability. On the other hand, species producing small seeds may germinate sooner and in habit new localities before other plants (SouZA \& FAGUNDES 2014).

\section{SUMMING UP AND FINAL CONCLUSIONS}

Mericarps sampled from plants reproduced generatively in cultivation were significantly longer and wider and, as a result, had higher volumes than these collected in in situ conditions. It was also found that mericarp shape expressed as the length/width ratio was more stable feature. It was also specified that mericarps collected in in situ conditions of Gniezno Lakeland are smaller in comparison to those collected from populations on Leszno Lakeland testing ground.

Plasticity in energy resource allocation confirms prior assumptions regarding a possible influence of 
environmental conditions on structures connected with generative reproduction (Mc GinLEY 1987, LEHTILA \& EHREL 2005). Strong intraspecific competition resulting from, e.g., cessation of grazing or lack of extensive recreation usage, forces creeping marshwort to increased production of leave and shoot biomass at the cost of flowering abundance and number of produced fruits. Mutations during intensive vegetative reproduction can also result in poor flowering. Biometric analysis conducted on mericarps from populations varying in their in situ condition, including a few crucial populations from Wielkopolska, encourages undertaking further research concerning life strategies and genetic diversification of $A$. repens, which should enable to more effectively protect this species of the highest level of concern and stop its populations recession in Poland.

\section{REFERENCES}

Chmiel J. (1985): Nowe i rzadsze gatunki we florze południowo-wschodniej części Pojezierza Gnieźnieńskiego. Part 1. Badania Fizjograficzne nad Polską Zachodnią, Seria B, Botanika 36: 161-169.

Chмiel J. (1987): Nowe i rzadsze gatunki we florze wschodniej części Pojezierza Gnieźnieńskiego. Part 2. Badania Fizjograficzne nad Polską Zachodnia, Seria B, Botanika 38: 67-79.

Chмiel J. (2013): Regionalna strategia zarządzania zasobami selerów błotnych Apium repens (Jacq.) Laq. w Wielkopolsce. Projekt zrealizowany na zlecenie Regionalnej Dyrekcji Ochrony Środowiska w Poznaniu zgodnie $z$ umową nr WOF.262.47.2013 $z$ dnia 1 sierpnia 2013. Typescript. Regionalna Dyrekcja Ochrony Środowiska, Poznań.

Chmiel J., Jackowiak B., Ziarnek K. (2014): Apium repens (Jacq.) Lag. - selery błotne (pęczyna błotna). In: R. Kaźmierczakowa, K. Zarzycki, Z. Mirek (eds). Polish red data book of plants. Pteridophytes and flowering plants. Instytut Ochrony Przyrody Polskiej Akademii Nauk, Kraków: 360-362.

Chmiel J., Ziarnek K. (2012): 1614 Selery błotne Apium repens (Jacq.) Lag. In: J. Perzanowska (ed.). Monitoring gatunków roślin. Przewodnik metodyczny. Part 2. Biblioteka Monitoringu Środowiska. Generalna Inspekcja Ochrony Środowiska, Warszawa: 243-259.

ERIKSsON O. (1999): Seed size variation and its effect on germination and seedling performance in the clonal herb Convallaria majalis. Acta Oecologica 20: 61-66.

HARPER J.L. (1977): Population biology of plants. Academic Press, London.

Jackowiak B., Celka Z., Chmiel J., Latowski K., ŻuKOWSKI W. (2007): Red list of vascular flora of Wielkopolska (Poland). Biodiversity Research and Conservation 5-8: 95-127.
Koczwara M. (1960): Rodzina: Umbelliferae, Baldaszkowate. In: W. Szafer, B. Pawłowski (eds). Flora polska. Rośliny naczyniowe Polski i ziem ościennych. Vol. 9. Państwowe Wydawnictwo Naukowe, Kraków.

LALONDE R.G., Roitberg B.D. (1989): Resource limitation and offspring size and number trade-offs in Cirsium arvense (Asteraceae). American Journal of Botany 76(8): 1107-1113.

Lehtila A.K., Ehrel J. (2005): Seed size as an indicator of sees quality: a case study of Primula veris. Acta Oecologica 28: 207-212.

Lembicz M., OlejnicZak P., ŻuKowski W., Bogdanowicz A. (2011): Effect of mother plant age on germination and size of seeds and seedlings in the perennial sedge Carex secalina (Cyperaceae). Flora 206: 158-163.

Lorenc H., Ceran M., Wita A., Laskowska A. (2006): Susza w Polsce - 2006 rok. Raport Instytutu Meteorologii i Gospodarki Wodnej, Warszawa.

MareK S., ZabaWSKi J. (1960): Interesujące spostrzeżenia florystyczne poczynione $\mathrm{w}$ Województwie Poznańskim w czasie dokumentacji torfowisk w latach 1955, 1960. Przyroda Polski Zachodniej 4(1-4): 133-139.

Mc Ginley M.A., Temme D.H., Geber M.A. (1987): Parental investment in offspring in variable environments: theoretical and empirical considerations. The American Naturalist 130(3): 370-398.

Mirek Z., Pięcoś-Mirkowa H., Zając A., Zając M. (2002): Flowering plants and pteridophytes of Poland. A checklist. W. Szafer Institute of Botany, Polish Academy of Sciences, Kraków.

Order No. 3/13 of Regional Directorate for Environmental Protection in Poznań of $4^{\text {th }}$ September 2013 (Act of Office of the Wielkopolskie Voivodeship, Poznań, $10^{\text {th }}$ September 2013, item 5113) on establishing plan of protection tasks for Natura 2000 Area Jezioro Brenno PLH300018.

ORDER of Regional Directorate for Environmental Protection in Poznań and Regional Directorate for Environmental Protection in Bydgoszcz of $2^{\text {nd }}$ September 2015 (Act of Office of the Wielkopolskie Voivodeship, Poznan $15^{\text {th }}$ September 2015, item 5276) amending the order on establishing plan of protection tasks for Natura 2000 Gniezno Lake District PLH300026.

Regulation of the Minister for Environment of $5^{\text {th }}$ January 2012 on plant species protection. Journal of Laws No. 0, item 81.

RogozińsKA A. (2012): Selery błotne (Apium repens) w Przemęckim Parku Krajobrazowym. Biuletyn Parków Krajobrazowych Wielkopolski 18(20): 29-48.

Ronse A.C., Popper Z.A., Preston J.C., Watson M.F. (2010): Taxonomic revision of European Apium L. s. I.: Helosciadium W.D.J. Koch restored. Plant Systematics and Evolution 287(1-2): 1-17. 
RutKowski L. (1998): Klucz do oznaczania roślin naczyniowych Polski niżowej. Wydawnictwo Naukowe PWN, Warszawa.

SADRAS O.V. (2007): Evolutionary aspects of the trade-off between seed size and number in crops. Field Crops Research 100: 125-138.

Schmid B., Dolt C. (1994): Effects of maternal and paternal environment and genotype on offspring genotype in Solidago altissima L. Evolution 48: 1525-1549.

Silvertown J. (1989): The paradox of seed size and adaptation. Trends in Ecology and Evolution 4: 24-26.

SouzA M.L., FAgundes M. (2014): Seed size as key factor in germination and seedling development of Copaifera langsdorffii (Fabaceae). American Journal of Plant Sciences 5: 2566-2573.

Szafer W., KulczyŃski S., PaWŁowski B. (1976): Rośliny polskie. Wydawnictwo Naukowe PWN, Warszawa.

Tutin T.G. (1968): Apium L. In: T.G. Tutin, V.E. Heywood, N.A. Burges (eds.), Flora Europaea. Vol. 2.
Rosaceae to Umbeliferae. Cambridge University Press. Cambridge: 351-352.

Ziarnek K., Ziarnek M., Dylawerski M., Dylawerska K. (2010): Występowanie Apium repens (Apiaceae) na Pomorzu Zachodnim. Fragmenta Floristica et Geobotanica Polonica 17(1): 59-66.

Żukowski W. (1961): Materiały do znajomości flory wschodniej Wielkopolski. Prace Komisji Biologicznej Poznańskiego Towarzystwa Przyjaciół Nauk 22(3): 1-30.

Żuкowski W. (1963): Notatki florystyczne z Wielkopolski. Fragmenta Floristica et Geobotanica Polonica 9(4): 463-467.

Żukowski W., Latowski K., Jackowiak B., Chmiel J. (1988): Apium repens (Jacq.) Lag. In: A. Jasiewicz (ed.). Materiały do poznania gatunków rzadkich i zagrożonych Polski. Floristica et Geobotanica Polonica 36(3-4): 284-290.

For citation: FloRKOwSKI K. (2017): Morphological variability of fruits in Apium repens (Jacq.) Lag. - a critically endangered species in Poland. Steciana 21(3): 85-92. doi: 10.12657/steciana.021.009 